\title{
Timber-framed wall panels with openings
}

\author{
E. Kozem Šilih \& M. Premrov \\ Faculty of Civil Engineering, University of Maribor, Slovenia
}

\begin{abstract}
This paper presents an experimental analysis of timber-framed wall elements with openings, coated with single fibre-plaster boards fastened to a timber frame. The present study is a continuation of the research work realized in recent years in the reinforcement of prefabricated timber-framed wall elements without any openings. Of course, in an apartment building, many walls may have one or more openings for functional reasons, doors or windows, where a concentration of the tensile stresses around the corners appears and consequently results in an essential decrease of the wall's bearing capacity and the horizontal stiffness. We tested three groups of test samples in order to carry out an appropriate research about the influence of the area of opening on the stiffness and load-carrying capacity of the panels. The measured values for the non-opening test samples were taken from the previous research work and were compared with the measured values of the timber-framed wall elements with openings.
\end{abstract}

Keywords: timber, frame walls, openings, fibre-plaster boards, experiments.

\section{Introduction}

There is an increasing tendency worldwide to build multi-level prefabricated timber structures with timber-framed walls as the main bearing capacity elements. As the treated timber-framed wall elements are a composite system composed of a timber frame and fibre-plaster coating boards that are connected to the timber frame by mechanical fasteners, it is possible to assure with suitable boundary conditions a composite behaviour between the boards and the timber frame along the whole element and consequently to increase the wall bearing capacity. Because the tensile strength of the boards is smaller than the strength of the timber frame, the boards present the weaker part of the treated composite system. The present study is a continuation of the research work realized in 
recent years in the reinforcement of prefabricated timber-framed wall elements without any openings. The results can be found in Premrov and Kuhta [1].

Of course, in an apartment building, many walls may have one or more openings for functional reasons, doors or windows (Figure 1), where a concentration of the tensile stresses around the corners appears and consequently results in an essential decrease of the wall's bearing capacity and the horizontal stiffness. Because of a very low tensile strength, which is approximately 10times lower than the compressive one, these stresses could be very dangerous in the case of fibre-plaster boards (FPB). Eurocode 5 [2] thus describes that the walls that contain a door or window opening should not be considered to contribute to the racking load-carrying capacity, Method A.

\section{Experimental studies}

\subsection{Test configuration}

In the following analysis we will limit our attention to the panel walls with window or door openings, with single fibre-plaster coating boards. We tested three groups of test samples in order to carry out an appropriate research about the influence of the area of opening on the stiffness and load-carrying capacity of the panels. All test groups $(\mathrm{O} 1, \mathrm{O} 2, \mathrm{O} 3)$ consisted of three panel walls, having actual dimensions of $\mathrm{h}=264 \mathrm{~cm}$ and $\mathrm{b}=125 \mathrm{~cm}$. The cross-section was composed of timber studs, timber girders and single Knauf fibre-plaster boards of thickness $t=15 \mathrm{~mm}$. They were fixed together to the timber frame using staples of $\Phi 1.53 \mathrm{~mm}$ at a constant spacing of $\mathrm{s}=7.5 \mathrm{~cm}$.

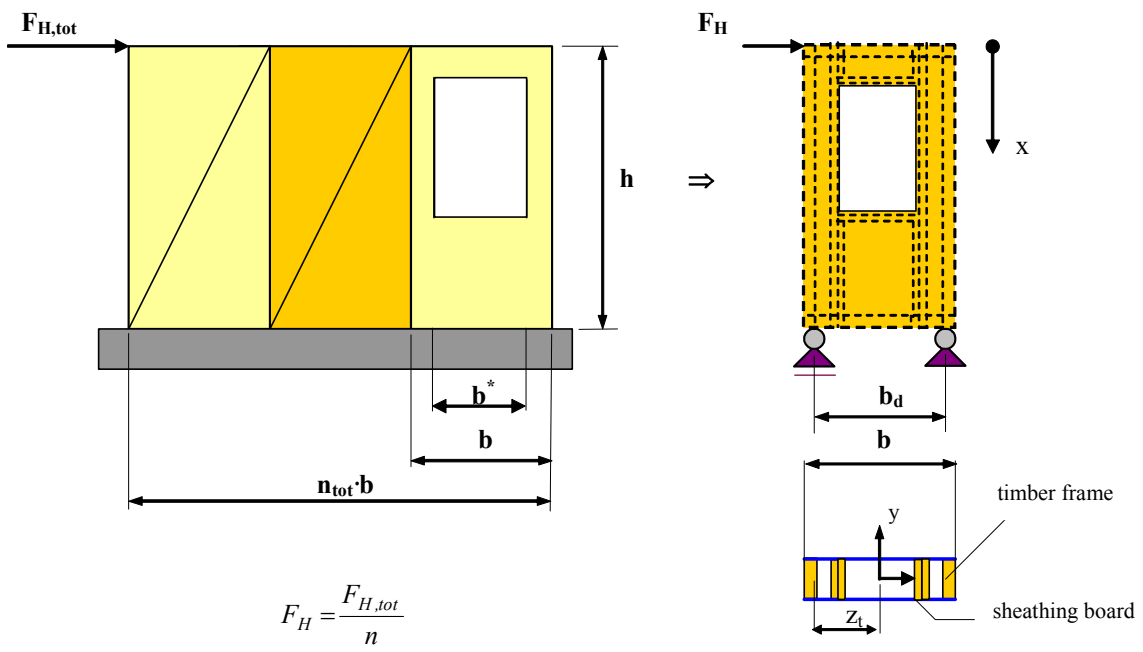

Figure 1: Static design for the wall assembly in one level. 
The sample groups $(\mathrm{O} 1, \mathrm{O} 2, \mathrm{O} 3)$ of nine test samples all together will be compared with the tested group (G2), presented by Premrov and Kuhta [1].

Test samples material properties for all groups were the same and are given in Table 1. Values for solid timber of quality C22 are taken from EN338 [3] and the characteristics of fibre-plaster boards from Knauf [4].

The static model according to Figure 1 was used for all three groups of test samples. The samples were actually rotated by $90^{\circ}$ according to Figure 2 and they were therefore subjected to vertical force acting at the end of the elements. To prevent lateral torsion buckling on free side of the element the vertical roller support was introduced.

The force forming the first crack $\left(F_{c r}\right)$ in the FPB, the ultimate failure force $\left(F_{u}\right)$, the maximal cantilever bending deflection $(w)$ under the acting force $\left(F_{H}\right)$ and the slip ( $\triangle$ ) in the tensile and compressive zone between the FPB, the timber frame and the opening were all measured. The measured values for the noopening test samples were taken from [1].

Table 1: $\quad$ Properties of the materials used.

\begin{tabular}{|l|c|c|c|c|c|c|c|}
\hline & $\begin{array}{c}\mathrm{E}_{0, \mathrm{~m}} \\
{\left[\mathrm{~N} / \mathrm{mm}^{2}\right]}\end{array}$ & $\begin{array}{c}\mathrm{G}_{\mathrm{m}} \\
{\left[\mathrm{N} / \mathrm{mm}^{2}\right]}\end{array}$ & $\begin{array}{c}\mathrm{f}_{\mathrm{m}, \mathrm{k}} \\
{\left[\mathrm{N} / \mathrm{mm}^{2}\right]}\end{array}$ & $\begin{array}{c}\mathrm{f}_{\mathrm{t}, 0, \mathrm{k}} \\
{\left[\mathrm{N} / \mathrm{mm}^{2}\right]}\end{array}$ & $\begin{array}{c}\mathrm{f}_{\mathrm{c}, 0, \mathrm{k}} \\
{\left[\mathrm{N} / \mathrm{mm}^{2}\right]}\end{array}$ & $\begin{array}{c}\mathrm{f}_{\mathrm{v}, \mathrm{k}} \\
{\left[\mathrm{N} / \mathrm{mm}^{2}\right]}\end{array}$ & $\begin{array}{c}\rho_{\mathrm{m}} \\
{\left[\mathrm{kg} / \mathrm{m}^{3}\right]}\end{array}$ \\
\hline $\begin{array}{l}\text { Timber } \\
\text { C22 }\end{array}$ & 1000 & 630 & 22 & 13 & 20 & 2.4 & 410 \\
\hline FPB & 3000 & 1200 & 4.0 & 2.5 & 20 & 5.0 & 1050 \\
\hline
\end{tabular}

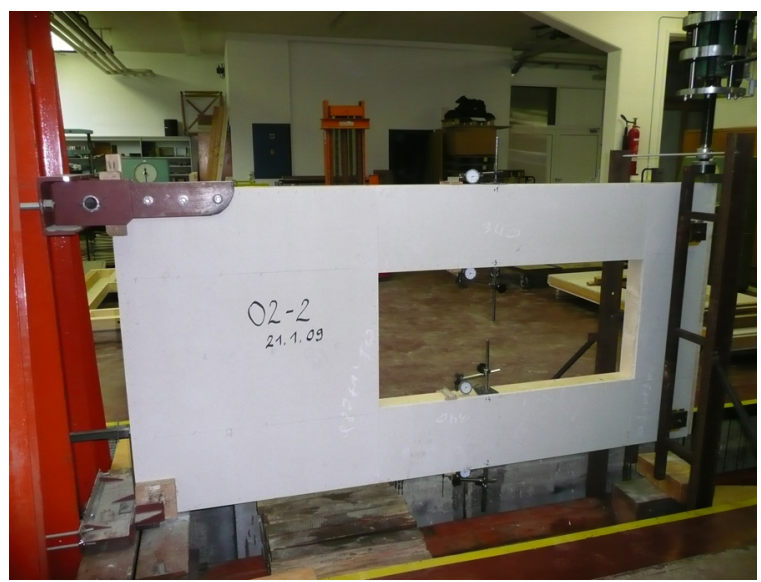

Figure 2: $\quad$ Static system of the test samples. 


\section{Description of wall panel specimens}

\subsection{The first group 01}

The first group of three test samples consisted of panel walls of actual dimensions $\mathrm{h}=264 \mathrm{~cm}$ and $\mathrm{b}=125 \mathrm{~cm}$. The dimensions of the opening is $\mathrm{h}_{\mathrm{o}}=$ $127.2 \mathrm{~cm}$ and $b_{o}=84.2 \mathrm{~cm}$. The cross-section presented in Figure 3 was composed of timber studs $(9 \times 9 \mathrm{~cm}$ and $4.4 \times 9 \mathrm{~cm})$, timber girders $(8 \times 9 \mathrm{~cm})$ and single Knauf fibre-plaster boards made of several pieces [4] of thickness $t=15$ $\mathrm{mm}$. They were fixed to the timber frame using staples of $\Phi 1.53 \mathrm{~mm}$ at a constant spacing of $\mathrm{s}=7.5 \mathrm{~cm}$.

\subsection{The second group $\mathrm{O} 2$}

The second group of three test samples consisted of panel walls of actual dimensions $\mathrm{h}=264 \mathrm{~cm}$ and $\mathrm{b}=125 \mathrm{~cm}$. The dimension of the opening is smaller than in the first group, $h_{0}=127.2 \mathrm{~cm}$ and $b_{0}=57.2 \mathrm{~cm}$. The cross-section presented in Figure 4 was composed of timber studs $(9 \times 9 \mathrm{~cm}$ and $4.4 \times 9 \mathrm{~cm})$, timber girders $(8 \times 9 \mathrm{~cm})$ and single Knauf fibre-plaster boards made of several pieces of thickness $t=15 \mathrm{~mm}$. They were fixed to the timber frame using staples of $\Phi 1.53 \mathrm{~mm}$ at a constant spacing of $\mathrm{s}=7.5 \mathrm{~cm}$.

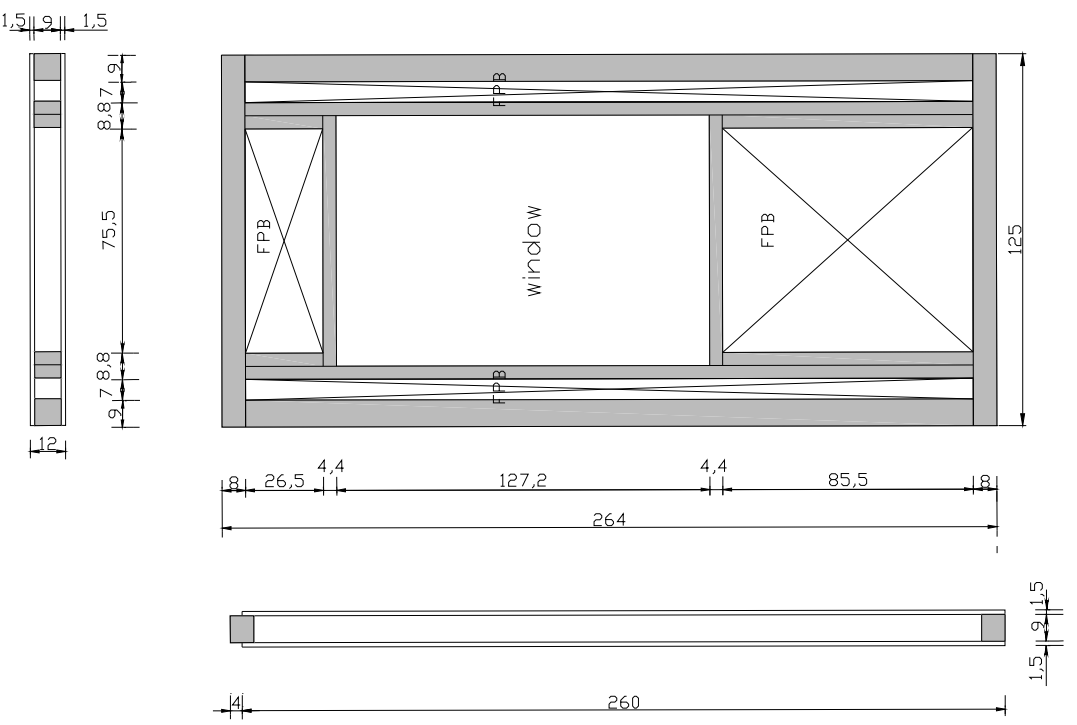

Figure 3: Cross-section of the test sample for the first test group (O1). 


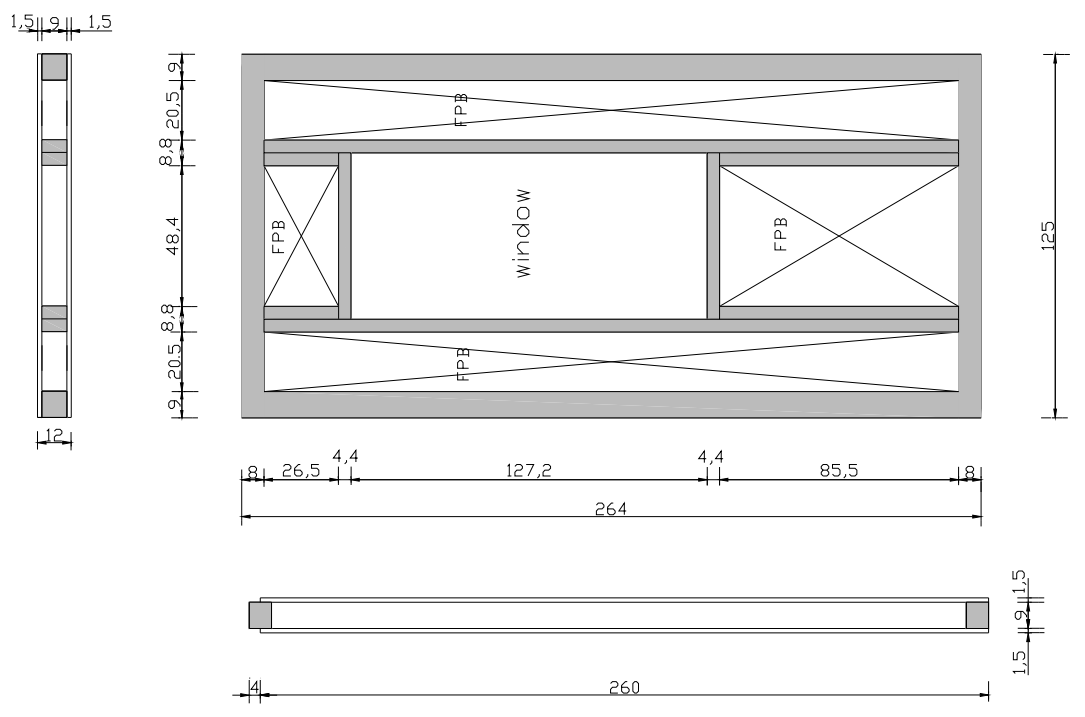

Figure 4: Cross-section of the test sample for the second test group (O2).

\subsection{The third group $\mathrm{O3}$}

The third group of three test samples consisted of panel walls of the same dimensions and the same material properties as the first group, but the single Knauf fibre-plaster boards are made of a single piece and the openings are cut out from the FPB. They were fixed to the timber frame using staples of $\Phi 1.53$ $\mathrm{mm}$ at a constant spacing of $\mathrm{s}=7.5 \mathrm{~cm}$.

\subsection{Group G2}

The group G2 of three test samples consisted of the no-opening wall panels of the same dimensions and the same material properties as the previous groups. The single Knauf fibre-plaster boards are made of a single piece. They were fixed to the timber frame using staples of $\Phi 1.53 \mathrm{~mm}$ at a constant spacing of $\mathrm{s}=$ $7.5 \mathrm{~cm}$. More details are described in Premrov and Kuhta [1]. The results are presented for information and comparison only.

\section{Test results and analysis}

Table 2 shows the ratios (in \%) between $\mathrm{F}_{\mathrm{cr}, \mathrm{i}} / \mathrm{F}_{\mathrm{cr}, \mathrm{G} 2}$ and $\mathrm{F}_{\mathrm{u}, \mathrm{i}} / \mathrm{F}_{\mathrm{u}, \mathrm{G} 2}$ and the "safety factors" $c_{i}$ obtained by the measured results.

The "safety factor" $\left(\mathrm{c}_{\mathrm{i}}\right)$ is declared as a quotient between the ultimate failure force $\left(\mathrm{F}_{\mathrm{u}}\right)$ and the force forming the first crack in FPB $\left(\mathrm{F}_{\mathrm{cr}}\right)$. Comparing, the safety factor $c_{1}=2.07$ for $\mathrm{O} 1(\mathrm{O} 3)$ and $\mathrm{c}_{2}=1.80$ for the $\mathrm{O} 2$ test group, we 
Table 2: $\quad$ Numerical results for $\mathrm{F}_{\mathrm{cr}}$ and $\mathrm{F}_{\mathrm{u}}$, their safety factors and ratios.

\begin{tabular}{|c|c|c|c|c|c|}
\hline \multirow{2}{*}{$\begin{array}{c}\text { Test } \\
\text { samples }\end{array}$} & \multirow{2}{*}{$\begin{array}{c}F_{c r} \\
(k N)\end{array}$} & \multirow{2}{*}{$\begin{array}{c}F_{u} \\
(k N)\end{array}$} & \multirow{2}{*}{$\begin{array}{c}\text { safety factor }\left(c_{i}\right) \\
F_{u} / F_{c r}\end{array}$} & \multicolumn{2}{|c|}{$\begin{array}{c}\text { Ratio } \\
(\%)\end{array}$} \\
\hline & & & & $\mathbf{F}_{\mathrm{cr}}$ & $F_{u}$ \\
\hline 01 & 4.30 & 8.91 & 2.07 & 25 & 34 \\
\hline $\mathrm{O} 2$ & 7.16 & 12.85 & 1.80 & 42 & 49 \\
\hline O3 & 4.31 & 8.95 & 2.07 & 25 & 34 \\
\hline G2 & 17.06 & 26.17 & 1.53 & 100 & 100 \\
\hline
\end{tabular}

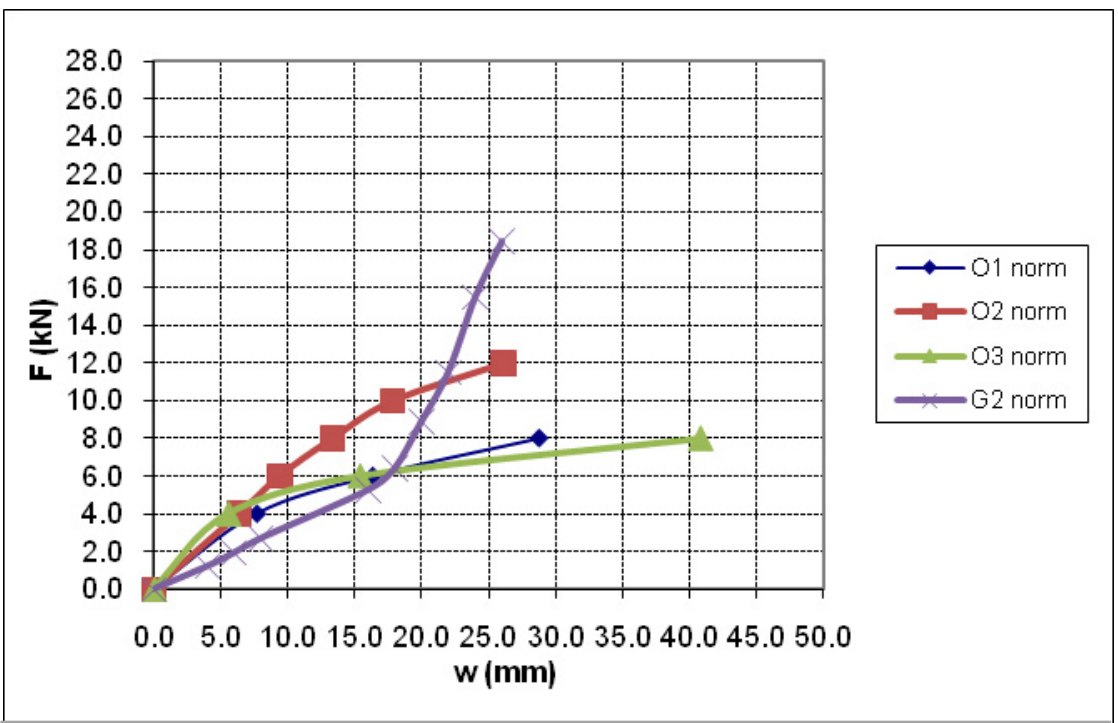

Figure 5: $\quad$ F-w diagram.

observe a big influence of the area of the opening. It is evident from the relationship between the measured forces forming the first crack, that the area of the opening is very important.

In addition, the elastic resistance (force forming the first crack) and especially the average failure force essentially depend on the area of wall panel opening. The influence is more evident by the failure force $\left(\mathrm{F}_{\mathrm{u}}\right)$. As expected, the force forming the first crack in the FPB above and below an opening, and consequently causes the failure of FPB around the corners of an opening. The stiffness of the connecting shear plane increased with smaller area of the opening according to composite behaviour. It can be concluded from the test results that in the second group (O2) of the test samples the first crack in the fibreboards appeared under a $66.51 \%$ greater horizontal force than in the first group (O1). This is important if we wish to improve only the elastic behaviour of the panels. In the second group the destruction force increased for $44.22 \%$ according to the first group. 


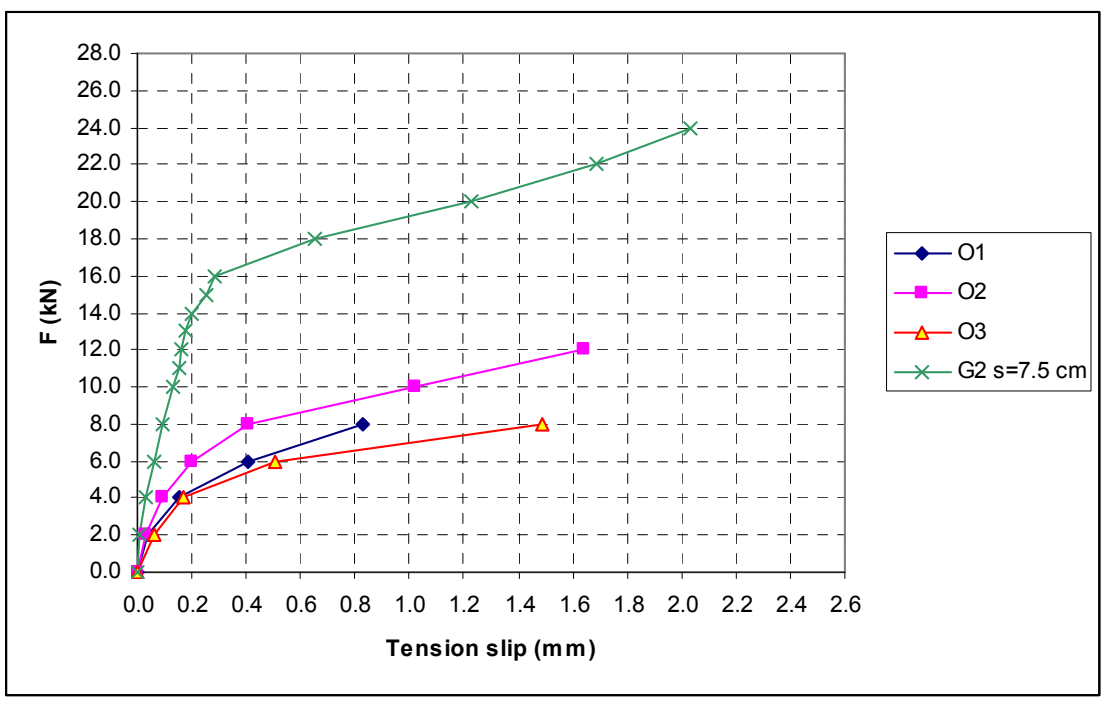

Figure 6: $\quad \mathrm{F}-\Delta_{\mathrm{t}}$ diagram.

To obtain better understanding about wall behaviour, Figure 5 presents an average measured vertical displacement (w) according to area of opening under the acting vertical force $(\mathrm{F})$.

Comparing test groups $\mathrm{O} 1$ and $\mathrm{O} 2$, it is obvious that the function inclination, which physically presents the stiffness, depends on the area of the wall panel opening. There is a clear difference when comparing the stiffness functions of O1-O3 with G2 test samples. Before any cracks appear in FPB, the bending stiffness of the G2 test samples is higher according to all other test groups. Therefore, we can conclude that no-opening wall panels have a relatively higher stiffness and load-bearing capacity than wall panels with openings.

The appearance of the first crack is noticed from F- $\Delta_{\mathrm{t}}$ diagram in Figure 6 and it is evident that slip before the first crack in FPB is higher for $\mathrm{O} 1$ samples and seems to be logical as the stiffness of the connecting shear plane is lower in this case.

Figure 7 shows the appearance of the first crack in the $\mathrm{O} 1$ test samples with single Knauf fibre-plaster boards made of several pieces. The dashed line presents the position of the glued connection between two pieces of FPB. It is obvious that the first crack has formed above the opening and not in the corner.

As seen in Figure 8, in the $\mathrm{O} 3$ test samples made of a single Knauf fibreplaster board, the first crack has appeared in the corner of the opening, which is expected from the analytical theory.

In the wall panel with opening and sheathed with a piece of FPB, side wall is bent because of the existence of wall parts above and below an opening, consequently causes the failure of FPB around the corners of an opening. In generally, there are not significant differences for stiffness and load-bearing capacity between the $\mathrm{O} 1$ and $\mathrm{O} 3$ test samples. 


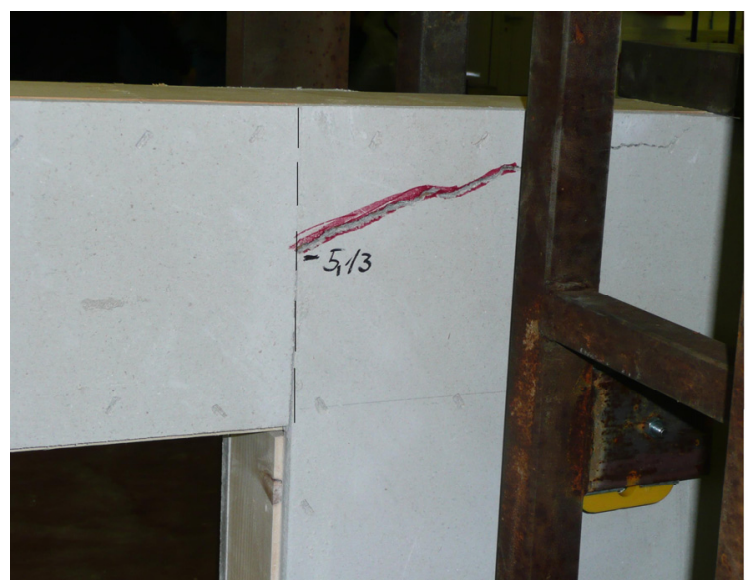

Figure 7: The appearance of the first crack in the $\mathrm{O} 1$ test samples.

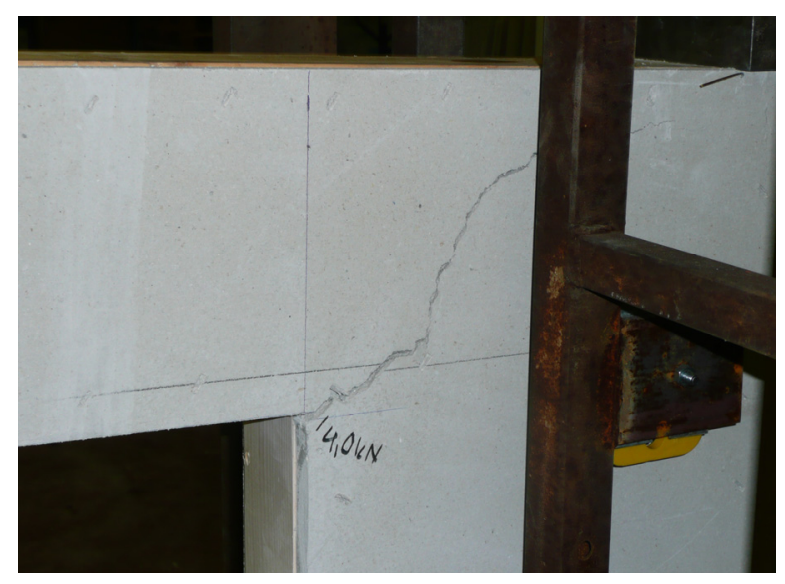

Figure 8: $\quad$ The appearance of the first crack in the $\mathrm{O} 3$ test samples.

\section{Conclusion}

We have proved that no-opening wall panels have a relatively higher horizontal stiffness and load-bearing capacity than wall panels with openings. However, the measured ultimate resistances of the wall panels with openings amounted from $30 \%$ to $50 \%$ of the ultimate resistances of the panels without openings. Therefore, we conclude, that the timber-framed wall elements which contain a door or window opening may be considered to contribute to the racking loadcarrying capacity, especially when a considerable part of the structure is made of such panels. Additionally, we present that the test samples made of several pieces $(\mathrm{O} 1)$ or of one piece (O3) of FPB with the area of opening of the same dimensions show practically identical experimental results. 


\section{References}

[1] Premrov M., Kuhta M., Influence of Fasteners Disposition on Behaviour of Timber-Framed Walls with Single Fibre-Plaster Sheathing Boards. Construction and Building Materials, 2008

[2] CEN/TC 250/SC5 N173. Eurocode5: Design of Timber Structures, Part 1-1 General rules and rules for buildings, EN 1995-1-1. Brussels 2004.

[3] European Committee for Standardization. EN 338:2003 E: Structural timber - Strength classes. Brussels 2003.

[4] Knauf Gipsfaserplatten Vidivall/Vidifloor 2002.

[5] Dobrila P., "Analitična in eksperimentalna analiza ojačanih panelnih sten". doktorska disertacija, Maribor, junij 2004 